\title{
Mortality distribution due to tracheal, lung, and bronchial cancer by gender, Brazil, 1980-2010
}

\author{
Distribuição da mortalidade por câncer de traqueia, pulmão e brônquios \\ no Brasil segundo sexo, 1980-2010
}

\author{
Raphael Mendonça Guimarães, Talami Sayole Costa Santos
}

\section{To the Editor:}

Lung cancer is the most common type of cancer worldwide in terms of mortality and incidence. ${ }^{(1)}$ The Brazilian National Cancer Institute estimates that, in 2010 in Brazil, there were 27,630 new cases of lung cancer, which became the second and fourth most common type of cancer among men and women, respectively, ${ }^{(2)}$ with a high burden of disease attributable to it. ${ }^{(3)}$

One group of authors, ${ }^{(4)}$ evaluating the age-period-cohort effect, stated that, with respect to the age effect, the risk of mortality increases with age, beginning at an early age. Regarding the cohort effect, those authors reported that there is a lower risk of mortality among men born after 1950 and an increasing risk in all groups of women. Finally, the results regarding younger generations indicate that the current trend is likely to continue; the cohort effect among women suggests a trend toward an increase in mortality rates, whereas a decrease in mortality rates among men under 65 years of age suggests that this trend will continue.

Studies of trends in lung cancer mortality in Brazil, published in the Brazilian Journal of Pulmonology, ${ }^{(5,6)}$ revealed that the age-adjusted mortality rate among men increased from 10.6 deaths/100,000 population in 1979 to 13.1 deaths/100,00 population in 2004. Over the same period, that rate increased from 3.0 to 5.4 deaths/100,000 population among women. Mendonça et al. ${ }^{(7)}$ observed that, although the magnitude of lung cancer mortality is greater among men, the increase in the age-adjusted mortality rate was much greater among women $(80 \%)$ than among men $(23.6 \%)$ in the study period (1979-2003).

Five years after those studies were published, however, a different behavior can be seen by observing the trend in mortality, stratified by gender. Figure 1 shows the linear trend in mortality from tracheal, lung, and bronchial cancer by gender.
Between 1980 and 2010, the linear trend shows an increase in mortality for both genders, although of different magnitudes for the rate and the trend. However, joinpoint regression analysis, which allows adjustment of data from a series on the basis of the smallest possible number of joinpoints (zero, i.e., a line with no joinpoints) and tests whether the inclusion of more joinpoints is statistically significant, showed that the trend behavior is different for each gender (Table 1). After adjustment, the apparent fluctuation for the male gender is explained by different trends in the period, with an increase in mortality between 1980 and 1995 (significant) and between 2000 and 2005, as well as a decrease in mortality between 1996 and 2001 and between 2006 and 2010 (significant). For women, in contrast, there is a homogeneous upward trend over the entire period, linearly.

The study of mortality by means of time trend analysis can be a useful instrument for assessing tracheal, lung, and bronchial cancer, given that it provides a source of information to support the decision-making policy, and it can serve as a tool to aid in assessing the impact of the prevention measures that are being implemented.$^{\left({ }^{8}\right)}$ In addition, time trends can reflect differences in population structure (such as age), as well as access to health care and the quality of care. Mortality rates are also affected by disease risk and protective factors, which can change over time and affect different population groups. ${ }^{(8)}$

In 1996, Brazil enacted a federal law (number 9,294/96) that restricts the use-as well as the advertising-of tobacco products in collective environments, whether public or private, except for areas designated for such consumption (also known as smoking areas), provided that they are isolated and ventilated..$^{(9)}$ In addition, in order to be in closer compliance with Article 8 of the Framework Convention on Tobacco 
Table 1 - Estimates of temporal trends in cause-specific mortality rates for tracheal, lung, and bronchial cancer on the basis of cut-off points determined by joinpoint regression. Brazil, 1980-2010.

\begin{tabular}{|c|c|c|c|c|c|c|}
\hline \multirow[t]{2}{*}{ Variable } & \multirow[t]{2}{*}{ Gender } & \multirow[t]{2}{*}{ Period } & \multirow[t]{2}{*}{ AAPC } & \multicolumn{2}{|c|}{$95 \% \mathrm{Cl}$} & \multirow[t]{2}{*}{$\mathrm{p}$} \\
\hline & & & & LL & UL & \\
\hline \multirow{5}{*}{$\begin{array}{l}\text { CSMR for } \\
\text { tracheal, lung, } \\
\text { and bronchial } \\
\text { cancer }\end{array}$} & \multirow{4}{*}{ Male } & $1980-1995^{*}$ & 1.2 & 0.9 & 1.5 & \multirow[t]{4}{*}{0.001} \\
\hline & & $1996-2001$ & -1.1 & -2.5 & 0.4 & \\
\hline & & 2002-2005 & 2.0 & -1.2 & 5.4 & \\
\hline & & $2006-2010^{*}$ & -3.1 & -4.5 & -1.7 & \\
\hline & Female & $1980-2010^{*}$ & 2.5 & 2.3 & 2.6 & 0.021 \\
\hline
\end{tabular}

CSMR: cause-specific mortality rates; AAPC: average annual percent change; LL: lower limit; and UL: upper limit. *Significant differences.

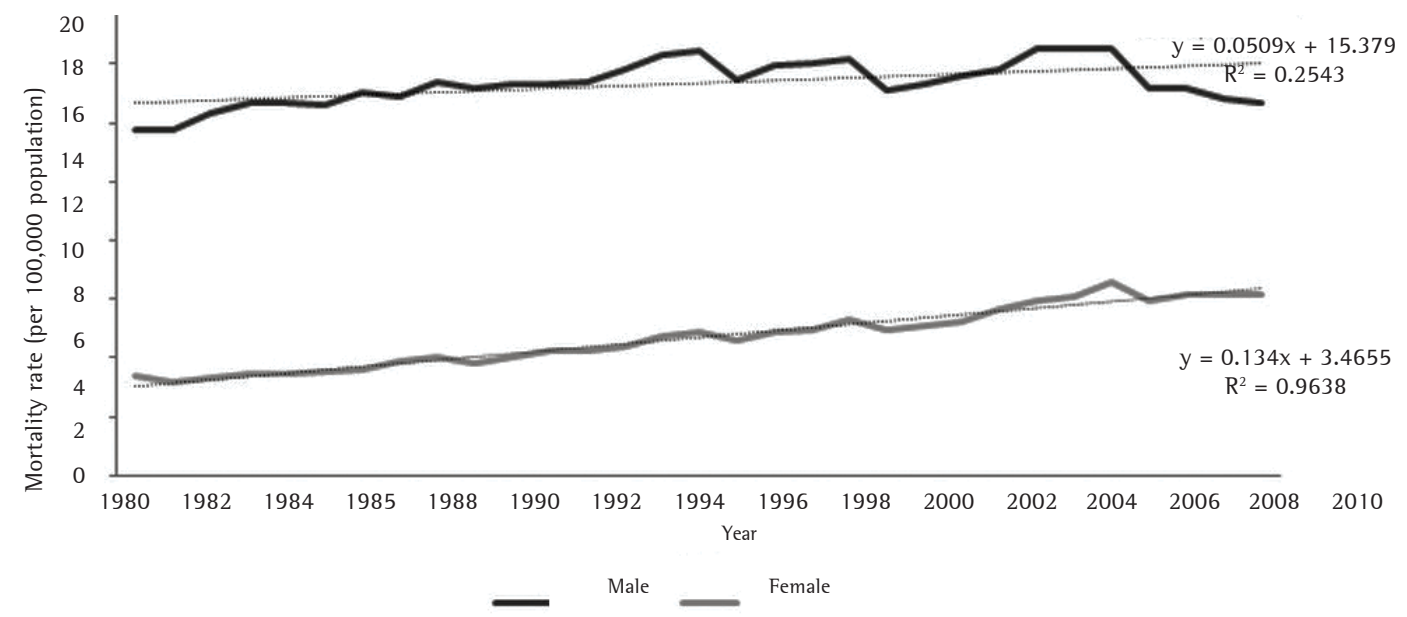

Figure 1 - Linear trend in mortality from lung, tracheal, and bronchial cancer by gender. Brazil, 1980-2010.

Control, ${ }^{(10)}$ an international treaty developed by the World Health Organization, to which Brazil is a signatory, states and municipalities have developed laws that eliminate smoking areas and prohibit the consumption of cigarettes, cigars, pipes, and cigarillos in bars, restaurants, nightclubs, schools, supermarkets, shopping centers, common areas in condominiums and hotels, etc. ${ }^{(10)}$

The smoking control policy in Brazil has been successful in preventing smoking initiation among young people. However, it is possible that it affects genders, social classes, and age groups differently. The data presented suggest that the dynamics of smoking prevalence in Brazil vary as a function of gender. Therefore, effective interventions for smoking cessation and for reducing smoking initiation among young people should be considered priorities, because they are really necessary to reduce lung cancer and other smoking-related diseases.
Raphael Mendonça Guimarães Adjunct Professor, Institute of Collective Health Studies, Federal University of Rio de Janeiro, Rio de Janeiro, Brazil

\section{Talami Sayole Costa Santos} Student in Health Promotion and Human Development, Institute of Collective Health Studies, Federal University of Rio de Janeiro, Rio de Janeiro, Brazil

\section{References}

1. Ferlay J, Shin HR, Bray F, Forman D, Mathers C and Parkin DM. GLOBOCAN 2008 v2.0, Cancer Incidence and Mortality Worldwide: IARC CancerBase No. 10 [Internet]. Lyon, France: International Agency for Research on Cancer; 2010 [cited 2013 Jan 1]. Available from: http:// globocan.iarc.fr

2. Instituto Nacional de Câncer. Estimativa 2010: incidência de câncer no Brasil. Rio de Janeiro: Instituto Nacional de Câncer; 2009. 
3. Schmidt Ml, Duncan BB, Azevedo e Silva G, Menezes AM, Monteiro CA, Barreto SM, et al. Chronic non-communicable diseases in Brazil: burden and current challenges. Lancet. 2011;377(9781):1949-61. http://dx.doi.org/10.1016/ S0140-6736(11)60135-9

4. Souza MC, Vasconcelos AG, Cruz OG. Trends in lung cancer mortality in Brazil from the 1980s into the early 21st century: age-period-cohort analysis. Cad Saude Publica. 2012;28(1):21-30. http://dx.doi.org/10.1590/ S0102-311X2012000100003 PMid:22267062

5. Boing AF, Rossi TF. Temporal trend in and spatial distribution of lung cancer mortality in Brazil between 1979 and 2004: magnitude, regional patterns, and genderrelated differences. J Bras Pneumol. 2007;33(5):544-51. PMid:18026652

6. Malta DC, Moura Ld, Souza Mde F, Curado MP, Alencar $\mathrm{AP}$, Alencar GP. Lung cancer, cancer of the trachea, and bronchial cancer: mortality trends in Brazil, 1980-2003. J Bras Pneumol. 2007;33(5):536-43. PMid:18026651

7. Silva GA, Noronha CP, Santos MO, Oliveira JF. Diferenças de gênero na tendência de mortalidade por câncer de pulmão nas macrorregiões brasileiras. Rev Bras Epidemiol. 2008;11(3):411-9. http://dx.doi.org/10.1590/ S1415-790X2008000300008

8. González Diego P, Jiménez Buñuales MT, Viñes JJ. Effect of birth cohort, period of diagnosis and age on cancer incidence in Navarra, 1973-1997 [Article in Spanish]. An Sist Sanit Navar. 2005;28(3):389-402. PMid:16421617

9. Brasil. Casa Civil. Lei no 9.294, de 15 de julho de 1996. Dispõe sobre as restrições ao uso e à propaganda de produtos fumígeros, bebidas alcoólicas, medicamentos, terapias e defensivos agrícolas, nos termos do $\S 4^{\circ}$ do art. 220 da Constituição Federal.

10. Instituto Nacional de Câncer. Convenção-quadro para o controle do tabaco. Texto oficial. Rio de Janeiro: INCA; 2011.

Submitted: 08 January 2013. Accepted, after review: 16 January 2013. 